Portland State University

PDXScholar

6-16-2021

\title{
A Study of Stable Isotopes in Snow on Mt. Hood, Oregon
}

Maya Felix

Portland State University

Follow this and additional works at: https://pdxscholar.library.pdx.edu/honorstheses

Part of the Geology Commons, and the Hydrology Commons Let us know how access to this document benefits you.

\section{Recommended Citation}

Felix, Maya, "A Study of Stable Isotopes in Snow on Mt. Hood, Oregon" (2021). University Honors Theses. Paper 1054.

https://doi.org/10.15760/honors.1080

This Thesis is brought to you for free and open access. It has been accepted for inclusion in University Honors Theses by an authorized administrator of PDXScholar. Please contact us if we can make this document more accessible: pdxscholar@pdx.edu. 


\title{
A study of stable isotopes in snow on Mt. Hood, Oregon
}

by

\author{
Maya Felix
}

An undergraduate honors thesis submitted in partial fulfillment of the requirements for the degree of

Bachelor of Science

in

University Honors

and

Geology

Thesis Advisor

Dr. John Bershaw

Portland State University

2021 


\section{ABSTRACT}

Over the 2020-2021 Winter, event-based and end-of-season snow samples were collected on Mt. Hood near Government Camp, Oregon and analyzed for their stable isotopic compositions of ${ }^{18} \mathrm{O}$ and ${ }^{2} \mathrm{H}$. It was found that surficial snow collected through the winter had higher variation in isotopic values than samples from a snow pit collected in spring. This suggests homogenization occurred in the snowpack over the season from snow metamorphism, sublimation, and/or melting. Homogenization of the snowpack will likely become more pronounced as temperatures increase and rain falls more often than snow due to climate change. Research that utilizes the snowpack as a proxy for precipitation may become less reliable due to this modification from isotopic redistribution.

\section{INTRODUCTION}

Stable isotopes in water have become an integral tool in Earth Science (e.g. Rozanski, 1993). They can be used to understand the hydrologic cycle and are an indicator of climate conditions. This is becoming increasingly more important in in the Pacific Northwest, where temperatures are expected to increase and precipitation is more likely to fall as rain than snow due to climate change (Jung and Chang, 2011). Precipitation, specifically snow, is the largest factor controlling streamflow. Seasonal snowmelt greatly contributes to runoff in the spring as well as groundwater recharge, albedo, and sustaining glaciers and snowfields (Taylor et al., 2018). A lack of snow and ice accumulation will deplete the seasonal stream discharge and inhibit normal water supplies (Dello, 2012). Therefore, it is important to have reliable methods of tracking water at all stages of the hydrologic cycle.

Event-based snow samples tell us different information than end-of-season snowpack samples, even at the same location. Over time, the snowpack is altered by snow metamorphism which results 
in snow that is isotopically different from its original composition at deposition. Recognizing how this modification changes the snowpack is important for snow hydrology and isotopic paleoclimate studies which rely on ice and firn core averages to understand changes in precipitation and atmospheric circulation over time (Taylor et al., 2018).

\section{BACKGROUND}

Unlike radiogenic isotopes, such as Carbon-14, stable isotopes are atoms of the same element with different masses which do not decay. In stable isotope hydrology, oxygen and hydrogen stable isotopes $\left({ }^{18} \mathrm{O}\right.$ and ${ }^{2} \mathrm{H}$, or Deuterium) are commonly used due to their abundance (Beria et al., 2018). These are expressed as a ratio of heavier isotopes to lighter isotopes relative to a standard. For example, the delta-value $\delta^{18} \mathrm{O}$ represents the ratio of heavier ${ }^{18} \mathrm{O}$ isotopes to lighter, but more common, ${ }^{16} \mathrm{O}$ isotopes in a sample.

$$
\delta^{18} O \text { or } \delta^{2} H=\frac{R_{\text {Sample }}-R_{\mathrm{VSMOW}}}{R_{\mathrm{VSMOW}}} \times 1,000
$$

$\mathrm{R}_{\text {Sample }}$ is the isotope ratio of the sample, which is reported relative to the isotopic ratio for a standard known as Vienna Standard Mean Ocean Water, Rvsmow, maintained by the International Atomic Energy Agency. If the delta-value is negative, this means the sample is more depleted in heavy isotopes when compared to VSMOW. Similarly, a positive value signifies the sample is more enriched in heavy isotopes compared with VSMOW (Beria et al., 2018).

These ratios can change during the hydrologic cycle, as the heavier ${ }^{18} \mathrm{O}$ is preferentially precipitated as rain or snow from vapor in the atmosphere, a process known as isotopic fractionation (Aizen et al., 2005). Stable isotopes in water can also be altered through snow metamorphism. When snow sublimates or melts, it then percolates as a liquid or gas through the surrounding snowpack causing fractionation and isotopic redistribution (Taylor et al., 2001). This diffusion can change the $\delta^{18} O$ values of material beneath the surface from its original isotopic 
composition to a more homogenized composition (Schlosser et al., 2002; Johnsen et al., 2000). In this study, I compare event-based snow samples with end-of-season snow pit samples to investigate the extent to which this isotopic alteration is occurring on Mt. Hood, Oregon.

\section{GEOLOGIC SETTING}

Mt. Hood is an active stratovolcano of the Cascade Range reaching over 11,000 feet $(3,426 \mathrm{~m})$ in elevation. Formed as a part of the Cascadia subduction zone, it is the tallest peak in Oregon and sixth tallest in the volcanic arc. The mountain harbors numerous glaciers and snowfields contributing to a tremendous watershed which drains into Oregon's many rivers, providing water for surrounding cities, agriculture, and wildlife.

My sampling location at Enid Lake sits just West of Oregon's rain shadow near Government Camp, Oregon which receives an annual average snowfall of about 250 inches (US Climate Data, 2019). It is surrounded by a marsh which extends to the east as well as dense forest. The small lake is drained by a few narrow creeks and sits at 3,630 ft (about 1,106 m) in elevation. The location was chosen for its easy access as well as lack of canopy cover. 


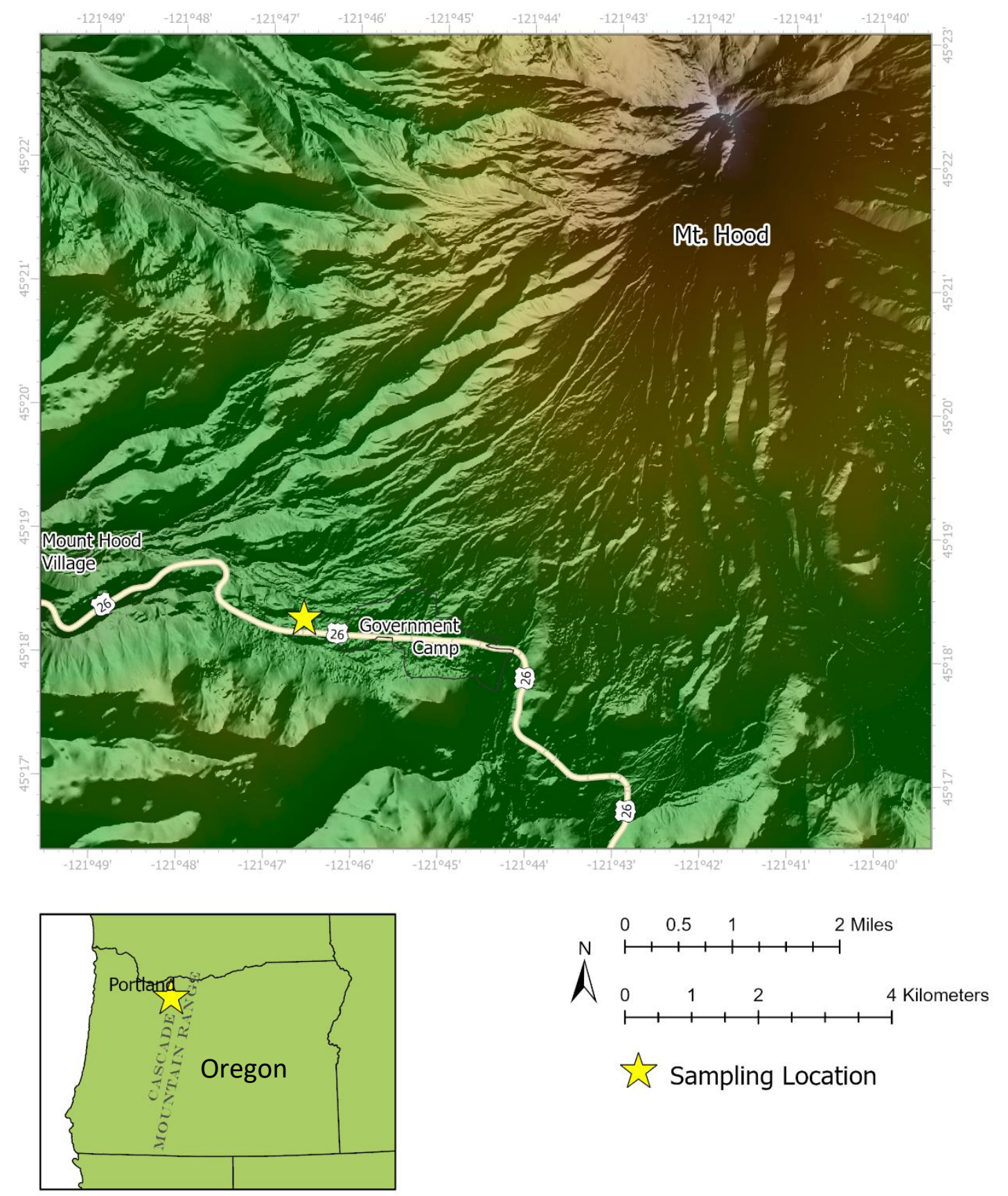

Figure 1: Location map of Enid Lake in Government Camp, Oregon. The sampling site is shown with a yellow star at both local and state levels. 


\section{METHODS}

From late December 2020 to mid-March 2021, surficial snow samples were taken at Enid Lake in Government Camp, Oregon (Figure 1). The samples were taken from fresh, surface snow between the tree line and shore of the lake (Figure 2). The site was visited after storm events which accumulated at least several inches of snow based on Government Camp weather records. When there were no significant storm events, the site was visited two weeks after the previous trip. Snow was packed into $15 \mathrm{~mL}$ centrifuge tubes and sealed before being shipped to Iowa State University Stable Isotope Lab where they were analyzed by a laser absorption spectrometer (Picarro L1102-i Isotopic Liquid Water Analyzer). Two surficial samples were taken during each trip, totaling 14 samples. Because of the duplicate samples, only half are used in this analysis.
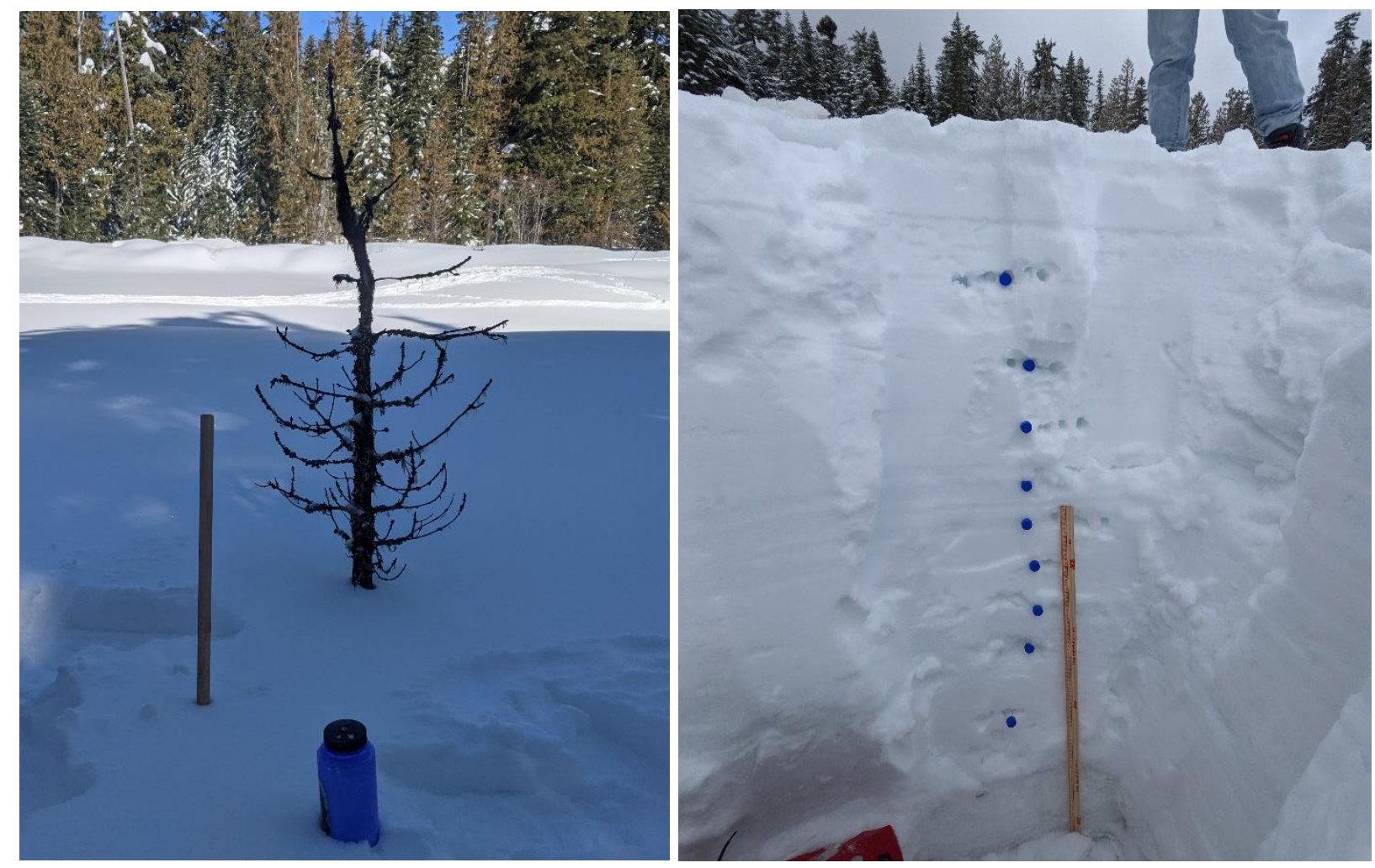

Figure 2: Photo of Enid Lake sampling site surface (left) and March $15^{\text {th }}$ snow pit (right). Blue caps in snow pit show depth of samples taken. 
On March $15^{\text {th }}$, at the end of the Winter season, samples were taken from a snow pit at the same sampling location. The pit was dug about $2 \mathrm{~m}$ deep (Figure 2) to the ground surface and snow was collected at varying depths, totaling 10 snowpack samples. These end-of-season samples then underwent the same process as the surface samples. Snow pit samples were similarly packed into vials and shipped to ISU lab for isotopic analysis of ${ }^{18} \mathrm{O}$ and ${ }^{2} \mathrm{H}$ (or $D$ ) with VSMOW as the reference standard. The combined uncertainty (analytical uncertainty and average correction factor) for $\delta 18 \mathrm{O}$ is $\pm 0.07 \%$ (VSMOW) and $\delta \mathrm{D}$ is $\pm 0.17 \%$ (VSMOW), respectively. One snow pit sample was lost due to contamination from organic material.

\section{RESULTS}

Results are shown in Table 1. Isotopic compositions for both the event-based snow and the snowpack (Figure 3) of $\delta^{18} O$ and $\delta D$ generally show the same pattern over time and depth. While the results here only discuss $\delta^{18} O$ values, similar patterns were observed in $\delta D$ results as well. Figures $3 a$ and $3 b$ have the same starting value (red triangle) which depicts the surficial sample taken the same day as the snow pit samples on March $15^{\text {th }}, 2021$. Both plots show variable $\delta^{18} O$ values with slight attenuation on the snow pit peaks compared with the surficial snow peaks. 
Table 1: Summary of isotopic data from end-of-season snow pit and event-based samples.

\begin{tabular}{|c|c|c|c|c|}
\hline & Date Collected & Sample Name & $\delta^{18} O$ & $\delta D$ \\
\hline \multirow{14}{*}{$\begin{array}{l}\text { Surficial } \\
\text { Samples }\end{array}$} & $12 / 20 / 2020$ & MH-MF-01 & -9.91 & -64.71 \\
\hline & $12 / 20 / 2020$ & MH-MF-02 & -11.61 & -83.97 \\
\hline & $1 / 2 / 2021$ & MH-MF-03 & -11.23 & -77.34 \\
\hline & $1 / 2 / 2021$ & MH-MF-04 & -13.00 & -90.21 \\
\hline & $1 / 16 / 2021$ & MH-MF-05 & -13.07 & -89.43 \\
\hline & $1 / 16 / 2021$ & MH-MF-06 & -12.75 & -87.29 \\
\hline & $1 / 30 / 2021$ & MH-MF-07 & -13.91 & -96.26 \\
\hline & $1 / 30 / 2021$ & MH-MF-08 & -15.07 & -105.41 \\
\hline & $2 / 20 / 2021$ & MH-MF-09 & -9.67 & -59.77 \\
\hline & $2 / 20 / 2021$ & MH-MF-10 & -9.72 & -61.25 \\
\hline & $2 / 28 / 2021$ & MH-MF-11 & -6.98 & -33.48 \\
\hline & $2 / 28 / 2021$ & MH-MF-12 & -6.81 & -32.36 \\
\hline & $3 / 15 / 2021$ & MH-MF-13 & -16.63 & -112.69 \\
\hline & $3 / 15 / 2021$ & MH-MF-14 & -16.24 & -112.16 \\
\hline \multirow{9}{*}{$\begin{array}{l}\text { Snow Pit } \\
\text { Samples }\end{array}$} & \multirow[t]{9}{*}{$3 / 15 / 2021$} & MF-MH-01P & -12.68 & -88.55 \\
\hline & & MF-MH-02P & -13.12 & -89.59 \\
\hline & & MF-MH-03P & -14.96 & -108.60 \\
\hline & & MF-MH-05P & -12.67 & -89.48 \\
\hline & & MF-MH-06P & -12.54 & -90.59 \\
\hline & & MF-MH-07P & -9.77 & -65.52 \\
\hline & & MF-MH-08P & -9.25 & -55.10 \\
\hline & & MF-MH-09P & -9.15 & -59.70 \\
\hline & & MF-MH-10P & -8.34 & -48.71 \\
\hline
\end{tabular}

The end-of-season snow pit was about $2 \mathrm{~m}$ deep, from the surface of the snowpack to the ground. The stratified snow showed alternating deposits of fine- to coarse-grained snow (Figure 3c). Finegrained layers consisted of soft and unpacked snow while the coarse-grained material was more consolidated, likely melted and refrozen snow. The very bottom of the snowpack was a thin bed of solid ice where the lowest snow pit sample was taken. 

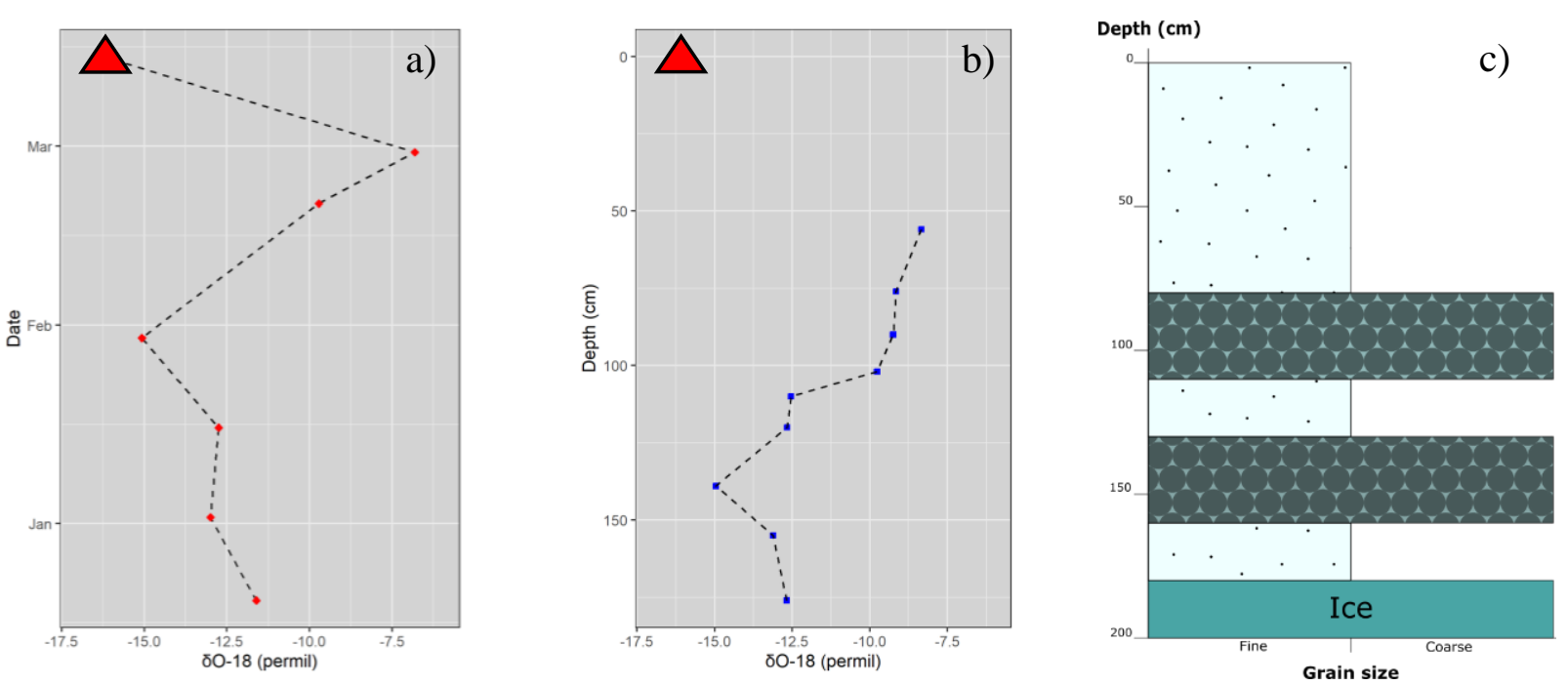

Figure 3: $\delta^{18} 0$ Composition of (a) surficial event-based samples versus (b) end-of season snow pit samples. (c) Generalized stratigraphic column for end-of-season snow pit. Red triangle represents the same sample plotted in both line graphs.

The surficial $\delta^{18} O$ values had an average of $-12.2 \%$ m $\pm 0.1 \%$ and a standard deviation of 3.2\%o. The end-of-season snow pit values averaged at $-11.9 \%$ $\pm 0.1 \%$ with a standard deviation of $2.5 \%$. Based on the standard deviations, the event-based samples show more variability in isotopic composition than samples in the snow pit. This distinction is similarly shown in Figure 4. The lateMarch sample (red triangle from Figure 3) has been omitted from the surficial data in this figure to better compare with older snow pit samples. Figures $4 \mathrm{a}$ and $4 \mathrm{~b}$ show a decrease in $\delta^{18} O$ going back in time and with depth. While both datasets show a trend based on linear regression, the $\mathrm{R}^{2}$ values indicate a significant correlation for snow pit data (0.63) and a poor fit for surficial data $(0.20)$. 

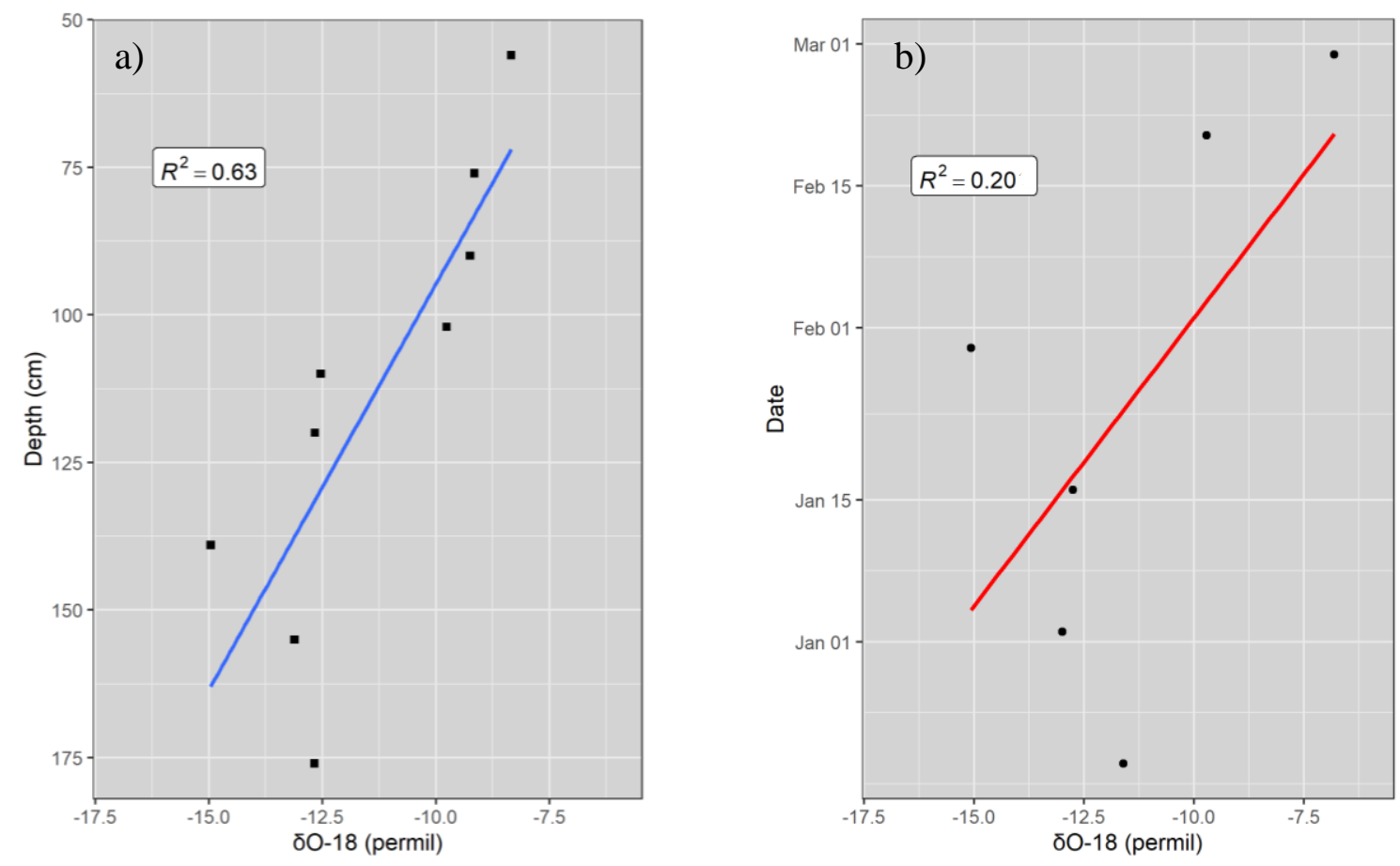

Figure 4: Comparison of regression lines for a) end-of-season snow pit samples and b) surficial eventbased samples including $\mathrm{R}^{2}$-values.

\section{DISCUSSION}

There is a moderate difference in standard deviations of $\delta^{18} O$ between event-based snow samples and equivalent end-of-season snow pit samples (2.5\% for snow pit samples and 3.2\%o for surface samples). Because this difference cannot be accounted for by analytical error $\left(<0.1 \%\right.$ for $\left.\delta^{18} O\right)$, this suggests the two datasets are relatively distinct. The regression in Figure 4 similarly depicts this contrast, as the $\mathrm{R}^{2}$-value (or correlation) is much lower in the surficial samples compared to the snow pit samples. The end-of-season snow pit appears attenuated relative to the event-scale isotopic dataset. This is characteristic of an altered snowpack and is consistent with isotopic homogenization (Schlosser, 2002).

The attenuation of isotopic values from the snow pit tells us that this snow has been changed since its deposition. A snowpack, theoretically, represents the seasonal accumulation of snow. Snow metamorphism, such as sublimation and melt-freeze, both contribute to homogenization of the 
snowpack. In both processes, lighter isotopes $\left({ }^{16} \mathrm{O}\right.$ and $\left.{ }^{1} \mathrm{H}\right)$ have preferentially evaporated or melted out of the deposit and percolated into the surrounding snowpack, or left the system entirely. It also results in a predictable decrease in $\delta^{18} O$ with depth as isotopically lighter snowmelt refreezes in deeper layers of the snowpack. This isotopic redistribution homogenizes the snow layers and results in isotopic compositions which no longer reflect the state of the snow at deposition.

In a warming climate, these isotopic averages are less likely to reflect snow at deposition as they are exposed to more metamorphism and more rain events in place of snow. These changes in snow accumulation will cause a bias in the snowpack, which obscures important information about precipitation and atmospheric circulation. I hypothesize that snow, firn, and ice cores will become less reliable for climate studies as the relationship between isotopes of precipitation and temperature is altered by the observed snow metamorphism (Schlosser et al., 2002). Further studies over longer time periods may be necessary to illustrate this point.

\section{CONCLUSION}

As temperatures rise and climate becomes more erratic, the methods used to study stable isotopes in hydrology must be incredibly reliable. By comparing surficial event-based samples of snow with end-of-season snow pit samples, I found that the snowpack is subject to modification over the season. Sublimation and melting cause an isotopic redistribution through the strata, resulting in a homogenized isotopic profile. This bias in the snowpack may be problematic for those who rely on these (and ice core) samples to understand precipitation and atmospheric conditions, as measured values may not closely reflect water at the time deposition. 


\section{REFERENCES}

Aizen (Eisen), V., Aizen, E., Fujita, K., Nikitin, S., Kreutz, K., and Takeuchi, N., 2005, StableIsotope Time Series and Precipitation Origin from Firn-Core and Snow Samples, Altai Glaciers, Siberia: Journal of Glaciology, v. 51, p. 637-654, doi: $10.3189 / 172756505781829034$.

Akers, P.D., Welker, J.M., and Brook, G.A., 2017, Reassessing the role of temperature in precipitation oxygen isotopes across the eastern and central United States through weekly precipitation-day data: Water Resources Research, v. 53, p. 7644-7661, doi:10.1002/2017WR020569.

Beria, H., Larsen, J.R., Ceperley, N.C., Michelon, A., Vennemann, T., and Schaefli, B., 2018, Understanding snow hydrological processes through the lens of stable water isotopes: WIREs Water, v. 5, p. e1311, doi:10.1002/wat2.1311.

Brooks, J.R., Wigington, P.J., Phillips, D.L., Comeleo, R., and Coulombe, R., 2012, Willamette River Basin surface water isoscape $(\delta 18 \mathrm{O}$ and $\delta 2 \mathrm{H})$ : temporal changes of source water within the river: Ecosphere, v. 3, p. art39, doi:https://doi.org/10.1890/ES11-00338.1.

Clark, I., and Fritz, P., 1997, Environmental Isotopes in Hydrogeology: CRC Press, p.1-78

Dello, K., 2012, Water and Climate in the Pacific Northwest:, https://water.oregonstate.edu/sites/water.oregonstate.edu/files/water_and_climate_in_the _pacific_northwest_v3.pdf.

Johnsen, S.J., Clausen, H.B., Cuffey, K.M., Hoffmann, G., and Creyts, T.T., 2000, Diffusion of stable isotopes in polar firn and ice: the isotope effect in firn diffusion: , p. 121-140, doi:10.7916/D8KW5D4X.

Jung, I.-W., and Chang, H., 2011, Assessment of future runoff trends under multiple climate change scenarios in the Willamette River Basin, Oregon, USA: Hydrological Processes, v. 25, p. 258-277, doi:https://doi.org/10.1002/hyp.7842.

Rozanski, K., Araguas-Araguas, L., Gonfiantini, R., 1993. Isotopic patterns in modern global precipitation. Climate change in continental isotopic records 78, 1-36.

Schlosser, E., and Oerter, H., 2002, Seasonal variations of accumulation and the isotope record in ice cores: A study with surface snow samples and firn cores from Neumayer Station, Antarctica: Annals of Glaciology - ANN GLACIOL, v. 35, doi: $10.3189 / 172756402781817374$.

Shannon, P., 2018, Water, Wildlife and Wonder: The Mt. Hood National Forest - National Forest Foundation: National Forest Foundation, https://www.nationalforests.org/ourforests/your-national-forests-magazine/water-wildlife-and-wonder-the-mt-hood-nationalforest (accessed November 2020). 
Stable Isotope Lab (SIL), https://siperg.las.iastate.edu/stable-isotope-lab-sil/ (accessed November 2020).

Taylor, S., Feng, X., Kirchner, J., Osterhuber, R., Klaue, B., and Renshaw, C., 2001, Isotopic evolution of a seasonal snowpack and its melt: Water Resources Research - WATER RESOUR RES, v. 37, doi:10.1029/2000WR900341.

Thompson, L., Mosley-Thompson, E., Davis, M., Lin, P.-N., and Mashiotta, T., 2003, Tropical Glacier and Ice Core Evidence of Climate Change on Annual to Millennial Time Scales: cc, v. 59, p. 137, doi:10.1023/A:1024472313775.

US Climate Data, Weather averages Government Camp, Oregon:, https://www.usclimatedata.com/climate/government-camp/oregon/united-states/usor0144 (accessed May 2021). 